\title{
BUSINESS MODELS IN THE SOCIAL ECONOMY - REVIEW OF SUCCESSFUL PRACTICES
}

\author{
K. Stoyanov*, G. Zhelyazkov \\ Department of Industry Business and Entrepreneurship, Faculty of Economics, \\ Trakia University, Stara Zagora, Bulgaria
}

\begin{abstract}
The social economy is a phenomenon that is gaining ever more significant dimensions, mainly because of its added value, which goes beyond measurable economic indicators. The role of enterprises operating in the social economy is also highly appreciated by the European Commission, which calculates their contribution to the European economy by more than $10 \%$ of its total. Because of the specificity and lack of specific legal rules, businesses use different business models to carry out their activities. The purpose of this study is to identify, define and evaluate the most commonly used business models of enterprises operating in the social economy, the so called third sector, analysing successful business practices. Using appropriate examples, including from Bulgaria, will be highlighted problematic issues for the functioning of social enterprises and some basic guidelines will be proposed to facilitate business operations in the social economy.
\end{abstract}

Key words: social entrepreneurship, solidarity economy, third sector JEL: L22, L31, O35

\section{INTRODUCTION}

For several years now, the use of the terms social economy, social entrepreneurship and social economy enterprises has begun to unify and combine overlapping organisations in scope and focus. However, expanding the number of participants identifying themselves as part of this ecosystem leads to a combination of different characteristics that make the exploration of the sector more challenging and difficult without introducing certain distinctions between the individual categories.

In addition, despite many years of focused efforts by various institutions at European level, such as the European Commission, the European Parliament, the Committee of the Regions and the Economic and Social Committee, the social economy in the European Union remains in the core focus and

\footnotetext{
*Correspondence to: Assist. Prof. Konstantin Stoyanov, PhD, Room 385, Faculty of Economics, Trakia University, Students Campus, 6000 Stara Zagora, Bulgaria, Tel: +35942699432, stoyanov.konstantin@gmail.com
}

competence of individual Member States. This is logical in itself, since social economy enterprises, despite their limitations, are an active part of economic life and their development and regulation, as in traditional trading companies and non-governmental organisations, falls within areas where the European Union rules does not prevail necessarily over the national legislation. As the EU has not an exclusive competence, defined in Article 3-6 of the Treaty on the Functioning of the European Union, therefore it cannot unilaterally draft and adopt legislative acts and oblige Member States to implement them.

The lack of synchronisation and joint efforts to establish a common framework for the social economy leads to natural disparities between countries, both in the approach and in the categorisation of enterprises operating in this sector. Differences can even be observed in a same country, depending on the level of autonomy of the decision-making process, the creation and management of specific policies at regional level. In this way, significant discrepancies are formed regarding the legal 
STOYANOV K., et al.

definitions, if any, the scope of the social economy and, of course, the extent of its development. Traditionally, as in all areas where there is no uniform European legislation, this allows some Member States to be leaders in the field, including in studying the characteristics of the social economy.

These differences, caused by some historical and political factors related to the development of individual countries, logically suggest different models of the existence of social economy enterprises. Based on this hypothesis, the article examines some of the most common business models of social enterprises, supported by specific examples of actually operating companies, including in Bulgaria. Last but not least, the newly adopted legal regulations categorising social economy enterprises in Bulgaria will also be addressed.

\section{METHODS}

In the first part of the study, which goal is to set a framework for the social economy that will be used, the main method complies of a literature review, aiming to identify leading trends in the field. An analysis of some aggregated official data available for public use and consultation was also carried out.

The second part of the study is about presenting some specific business models. To this end, the literature review and evaluation of some of the common business models will be complemented by case studies of actually operating companies in the sector.

\section{MAIN FINDINGS AND CONCLUSIONS}

One of the first documents in the European Union defining the social economy as a separate sector made up of social enterprises is the 2011 European Commission Communication on the Social Business Initiative - Creating a favorable climate for social enterprises, key stakeholders in the social economy and innovation. According to it, the social enterprise - participant in the social economy - is an enterprise whose main purpose is to exert beneficial social influence rather than to make a profit for the owners or the partners. It operates in the free market, delivering goods and services in an entrepreneurial and innovative way, and uses the generated profits primarily for social purposes. It is subject to responsible and transparent management, especially by involving its employees, customers and
The most recent conceptual definition of the term 'social economy', composed by representatives of the sector itself, can be found in the Charter of Principles of Social Economy developed by Social Economy Europe - the association representing the social economy at European level. These principles are:

- $\quad$ preponderance of personality and social purpose over capital;

- $\quad$ voluntary and open membership;

- democratic control by members (does not apply to foundations as they do not have members);

- $\quad$ reconciling the interests of members and users with the common interest;

- protection and implementation of the principles of solidarity and responsibility;

- autonomous governance and independence from public authorities;

- most of the surpluses are used to achieve sustainable development goals, services of interest to members, or the common interest.

According to the European Economic and Social Committee, which has initiated regular surveys every $4^{\text {th }}$ year on the social economy in Europe, through a report entitled "Recent evolutions of the Social Economy in the European Union ", the definition of the social economy must be common to the sector as its 2016 states. Thus, the definition is: "The set of private, formally-organised enterprises, with autonomy of decision and freedom of membership, created to meet their members' needs through the market by producing goods and providing services, insurance and finance, where decision-making and any distribution of profits or surpluses among the members are not directly linked to the capital or fees contributed by each member, each of whom has one vote, or at all events are decided through democratic, participatory processes. The SE also includes private, formallyorganised entities with autonomy of decision and freedom of membership that produce nonmarket services for households and whose surpluses, if any, cannot be appropriated by the economic agents that create, control or finance them".

According to the Law on the Enterprises of the Social and Solidarity Economy, which has been in force since 02.05.2019, an expanded definition of the social economy is being introduced, which includes and extends its 
scope, including that of the solidarity economy, which is also the trend in the leading countries in the European Union. The Act thus implies that the Social and Solidarity Economy is a form of entrepreneurship aimed at one or more social activities and / or social objectives pursued by enterprises, including through the production of various goods or the provision of services, in cooperation with the state, or local bodies, or independently. In addition, the sector rests on the following principles: social advantages over economic goals; association for public and / or collective benefit; publicity and transparency; independence from public authorities; participation of members, employees or employees in management decisions.

From the point of view of business models in the social economy, there are not many studies available in the literature, probably due to the limitations caused by the lack of an universal approach and the categorisation of enterprises in the sector. This implies a more fragmented approach with a national focus, which limits the applicability of the results as they involve many factors dictated by national characteristics, including the historical development of social enterprises and their various forms in the past. For example, and in accordance with the recently enacted Law on the Enterprises of Social and Solidarity Economy, in Bulgaria the sector includes cooperatives, non-profit legal entities for carrying out socially beneficial activity and social enterprises, which are further defined in the law and introduce a number of mandatory requirements for categorising an enterprise as social. However, according to an EESC/CIRIEC study conducted in 2016 on the development of the social economy in the EU, Bulgaria falls into the second category of countries where there is a moderate degree of acceptance of the concept of "social economy" along with Italy, Cyprus, Denmark, Finland, Sweden, Latvia, Malta, Poland, the United Kingdom, Greece, Hungary, Ireland, Romania and Slovenia.

In addition, according to the same survey, Bulgaria is one of the seven countries in the European Union to have National Plans to Promote the Social Economy between 2011 and 2016. The others in the list are Poland, Portugal, Romania, Spain, Sweden and the United Kingdom. The study of the European Economic and Social Committee does not
STOYANOV K., et al. make a qualitative assessment of the implementation and feasibility of the plans, which is important to emphasise.

With respect to the business models on which the activity of social entrepreneurship is based, it is expected that they are not clearly specified and defined in number and characteristics. Different authors and research teams offer different business models using different approaches and criteria in their qualification.

At the same time, one of the leading organisations dedicated entirely to the development of the social and solidarity economy, EMES European Research Network, uses its own approach in defining the business models of enterprises in the sector. Defourny \& Nyssens (2012) define 9 approaches of managing an enterprise in the sector of social and solidarity economy. Some differences are minimal, but they actually predetermine the methods used to finance the main activity, to redistribute revenues and to participate in the inclusive management of the company.

The main models in the social economy, according to EMES, are:

1. Emphasis on the active provision of goods and services as a source of financial income providing social impact;

2. Developing activities with significant economic risk, similar to traditional business practices;

3. Limitation of labour costs thanks to volunteering and other unpaid forms of labour in order to limit company costs;

4. A clearly defined goal of improving the living conditions of the local community or a marginalised group;

5. Entrepreneurial activity created and developed by a group of citizens or civic organisations with a specific and clear purpose and goal;

6. Enterprises with limited distribution of dividends among members in order to avoid maximising profits as a driving goal for the existence of the company;

7. High degree of independence in the management of the company, even in cases of dependence on public resources, guaranteeing free expression of opinion and decisions related to the development of the company, including its termination due to unsatisfactory economic indicators;

8. Companies in which the decisionmaking process is not directly related to the amount of financial participation of the persons 
involved in the management, but instead relies on the principle of one member, one vote;

9. Involvement of as many stakeholders as possible in the strategic decision-making and company development processes, including end clients and users of social services.

In another in-depth analysis, different type of division is applied to the types of business models in the social economy. Alter (2016) identifies seven major types of business models in social economy. She addresses major trends in the development of social enterprises, with an emphasis on Latin America, Central Africa and South Asia, but the developed governance models are applicable in other countries and regions. As a result of her research, the following models are identified:

1. Supporting entrepreneurial activity among self-employed persons and micro-firms through the provision of paid financial and business development services, and in the case of profit, it is directed toward the provision of additional social services;

2. Market mediation that allows target groups to reach the free market and sell their products. This is achieved through products improvement, provision of micro-credits and access to markets;

3. Employment and competences improvement of the target groups, most often persons with limited access to the labour market, by engaging them in existing social enterprises;

4. Commercialisation of the social services provided by the enterprise directly to the target groups or to third parties, i.e. the free market;

5. Subsidising the social services offered, using the financial profit generated by other activities of the social enterprise;

6. Social enterprises operating as a broker between the target group producers and the end user, often reminiscent of the traditional model of a cooperative association;

7. Social services are provided independently and are characterised as complementary to the core business of an existing and stable company with a high profit margin;

Another study on the problem by Grassl (2012), implies a new type of enterprise organisation in the social and solidarity economy, based on a hybridity between familiar models in social entrepreneurship. It
STOYANOV K., et al. adopts the 7 models of Alter (2016) as a base, adding additional two - a cooperative model and a model tailored to low-income groups. On this basis, it forms 5 hybrid models that may exist depending on the business environment in which they are developing and the strategy used by enterprises in the social and solidarity sector.

The five hybrid models are founded on some of the existing hybrid models observed in biology. Based on the different levels of copying methods used in the public and private sectors, they are:

1. Mimicry - a private sector company adopts fully the public sector company's approach ;

2. Grafting - an element from the model used in the public sector is perceived by a company in the private sector and this creates a new type of hybrid organisation;

3. Transplantation - an introduced element from the public sector company, creates a new complementary element in the private sector model;

4. Cross-fertilisation - transplantation followed by mimicry;

5. Mutation - transplant followed by grafting.

The existence of many different models in the social and solidarity economy is a testament to the dynamic development of the sector and its ability to adapt to different conditions of the business environment. However, some authors try to limit and simplify the available models by grouping them according to their different characteristics. For example, according to Monzón \& Herrero (2016), business models in the social economy can be reduced to three large groups, which generally meet the most important objectives recognised as key goals by the companies concerned.

Analysing several different approaches defining business models, including the one developed by EMES, the authors reach to the following three types of business models in the social economy:

1. Economic and commercial dimension, where companies relies mostly on their economic efficiency. In this regard, they are more like traditional businesses;

2. Social dimension in which the social effect and the maximum reach of the target groups defined by the companies are the driving force. 
3. Participative dimension in which the democratic decision-making process and the independence of local, regional or national authorities are leading. Their main goals are to avoid the influence of external funding organisations on the organisation, and to have equality among members.

Based on the types of business models studied in the social and solidarity economy and the current conditions for the development of the sector in Bulgaria, the last cited approach, limiting the different nuances and characteristics of companies, seems most appropriate. This is due to the fact that the legislation in the field is yet to be implemented and its most significant results can be analysed even further in time.

However, some of the existing and sustainable businesses, that identify themselves as social, may be suggested as examples of relevant types of business models.

Within the first category falls BLITAB, which is the world's first tablet for blind people. The Vienna-based start-up, founded by three Bulgarians, solves the biggest social problems of more than 285 million people worldwide, giving them digital access to information and education, leading to labour market access and equality. By itself, the end product is aimed at a vacant niche, while at the same time satisfying a social need and generating revenue for the company.

The second category includes the entrepreneurial initiative of the Foundation for Social Change and Inclusion. The social enterprise, called "HOPe SOAP", started in March 2012. The process of soap production is very suitable for young people from vulnerable groups who, due to their specific characteristics, are unable to succeed in the labour market. This activity engages their time with productive tasks, giving them a sense of utility, developing their problemsolving skills and enabling them to earn a decent income. The soaps are a source of income that will finance the enterprise itself.

As for the third group of models in the social economy, they are traditionally represented by the different forms of cooperatives that exist in Bulgaria. For a long time, they have been the only form of employment for vulnerable population groups. However, the concept of cooperation, according to the social and solidarity economy, is much closer to that in Italy, France or Spain, where local producers and even entire regions share their efforts and resources to reach more significant and distant markets that will
STOYANOV K., et al. guarantee them sustainability, larger incomes and increase in the well-being of the entire industry or region. Most importantly, in these cases all manufacturers are associated with one brand, usually acquired under certain conditions, which guarantees to the client the quality and origin of the goods.

In short, any business model of enterprises in the social and solidarity economy must cover some of the following conditions: be driven by a socially significant goal, lead to positive change in the local community, be guided by entrepreneurial principles and use management strategies to successfully sell its goods or services.

\section{REFERENCES}

1. Article 3-6 of the Treaty on the Functioning of the European Union.

2. European Commission, 2011, Communication from the Commission to the European Parliament, The Council, The European Economic and Social Committee and the Committee of the Regions: Social Business Initiative, Creating a favorable climate for social enterprises, key stakeholders in the social economy and innovation, COM/2011/0682

3 . Déclaration finale commune des organisations européennes de l'Économie Sociale, 2002, CEPCMAF, France

4. EESC/CIRIEC, 2012, The Social Economy in the European Union, European Economic and Social Committee, Brussels

5. Law on Enterprises of Social and Solidarity Economy, in force since 02.05.2019

6. EESC/CIRIEC, 2016, Recent evolutions of the Social Economy in the European Union, European Economic and Social Committee, Brussels

7. Defourny, J., Nyssens, M., 2012, The EMES approach of social enterprise in a comparative perspective, EMES European Research Network 8. Alter, S.K., 2006. Social enterprise models and their mission and money relationships. Social entrepreneurship: New models of sustainable social change, pp.205-232.

9. Grassl, W., 2012. Business models of social enterprise: A design approach to hybridity. ACRN Journal of entrepreneurship Perspectives, 1(1), pp.37-60

10. Monzón, J.L. \& Herrero, M. (2016), "Identificación y análisis de las característicasidentitarias de la empresa social europea: aplicación a la realidad de los Centros Especiales de Empleode la economía española”, CIRIEC-España, Revista de Economía Pública, Social y Cooperativa, 87:295-326 